\title{
Lisianthus cultivation using differentiated light transmission nets ${ }^{(1)}$
}

\author{
JULIA MARTELLA DE ALMEIDA(2), CRISTIANE CALABONI(2); PAULO HERCÍLIO VIEGAS RODRIGUES(2)*
}

\begin{abstract}
Lisianthus stands out as one of the ten most cut flowers sold in the world. The use of meshes in a different light transmission is gaining more space in horticulture with promising results in greenhouse. The aim of this study was to evaluate the development of lisianthus grown in different light transmission meshes in blue, black, red and control treatments, which were transplanted 20 seedlings to cultivate Snow white with three replications, and therefore, 60 plants 240 plants per treatment in total. Agronomic characteristics such as plant height and length of the top pair of leaves were evaluated at 15, 38, 59, 82 and 105 days after transplanting. Other features such as early flowering, thick stem, distance between us and weight of the harvested stems were obtained at harvest stage. At the end of the evaluations, the red net treatment consistent with a significant difference in stem height, with higher values in all the analysis dates with greater differences compared to treatment under blue net ranging $5.2 \mathrm{~cm}$ to 59 DAT at the end of this difference, being $12.56 \mathrm{~cm}$ to 106 DAT and earliness in flowering, wherein with the red net the harvest began 15 days before the treatment in the blue net.
\end{abstract}

Keywords: greenhouse, photoselective, flower culture

\section{RESUMO}

\section{Cultivo de Lisianthus em malhas de transmissão de diferentes colorações}

O Lisianthus destaca-se como uma das dez flores de corte mais comercializadas no mundo. O uso de malhas de transmissão de diferentes colorações ganha cada vez mais espaço na horticultura com os resultados promissores em cultivo protegido. $\mathrm{O}$ objetivo do presente trabalho foi avaliar o desenvolvimento da cultura do lisianthus em diferentes malhas de transmissão de luz, nos tratamentos azul, preta, vermelha e o controle, na qual foram transplantadas 20 mudas de cultivar Snow White, com três repetições, sendo, portanto, 60 plantas por tratamento e 240 plantas no total. Características agronômicas como altura das plantas e comprimento do maior par de folhas foram avaliadas aos 15, 38, 59, 82 e 105 dias após o transplantio. Outras características como início do florescimento, espessura da haste, distância entre nós e massa das hastes colhidas, foram obtidas na fase de colheita. Ao final das avaliações, o tratamento de malha vermelha foi o mais promissor com diferença significativa em altura da haste, apresentando valores superiores em todas as datas de análise com maiores diferenças em comparação ao tratamento sob a malha azul variando em 5,2 cm aos 59 DAT sendo no final essa diferença de 12,56 cm aos 106 DAT e precocidade no florescimento, sendo que com a malha vermelha a colheita teve início 15 dias antes do tratamento sob a malha azul.

Palavras-chave: cultivo protegido, fotosseletiva, floricultura

\section{INTRODUCTION}

The Lisianthus (Eustoma grandiflorum), an ornamental plant belonging to the Gentinaceae family, has a biennial cycle, however, it is normally cultivated as an annual plant. (BACKES et al., 2005; STRUWE and ALBERT, 2002). It may be grown throughout the year, practically without limitations when using acclimatized environments and specific varieties for each season of the year (HARBAUGH, 2007).

Grown mainly as a cut flower, it is outstanding on the Brazilian market because it produces single or double flowers, in a variety of colors and bi-colors, in addition to being long-lasting. Their production and popularity has grown worldwide, and they are considered one of the ten best-selling cut flowers (CORR and KATZ, 1997).

The use of differentiated light transmission networks in protected cultivation has presented promising results in increasing productivity and precocious development of some ornamental plants. Growing the Phalaenopsis orchid under a blue light network showed more vigorous vegetative growth, while the flower buds of plants grown under a red light network were more precociously induced. The blue and red networks, with $30 \%$ shade appear to be advantageous in comparison with the conventional black shade net, therefore a blue net is used for the vegetative stages of development, and the red net for flower induction (ITO et al., 2006).

Stamps and Chandler (2008) cited the effects of black, gray, blue and red nets, all with $70 \%$ shade, in the cultivation of Aspidistra elatior 'Variegata' (apidistra), Philodendron 'Xanadu' (Philodendron hybrid) and Pittosporum tobira 'Variegata' (Variegated Japanese Pittosporum). With Aspidistra greater height was attained

\footnotetext{
(1) Received in 04/05/2016 and accepted in 01/08/2016

(2) Universidade de São Paulo (USP), Escola Superior de Agricultura Luiz de Queiroz (ESALQ), Piracicaba-SP, Brazil. *Corresponding author: phrviegas@usp.br
} 
under the gray net, when compared with the other nets. The Philodendron plants were shorted under red and black shade nets, in comparison with blue and gray nets. Whereas, with Pittosporum the internode length in plants cultivated under red nets was longer and consequently resulted in taller plants in comparison the other plants cultivated under the other nets.

In the present study, the aim was to evaluate the effect of spectral light quality, by using differentiated light transmission nets, on the agronomic characteristics in the cultivation of Lisianthus.

\section{MATERIALS AND METHODS}

The material used with lisianthus of the Snow White cultivar, specifically for winter planting, supplied by SAKATA. The trial was implanted on $13 / 06 / 2014$, in the municipality of Piracicaba, SP, Brazil, in a greenhouse with transparent plastic covering and Chromatinet (Polysak Plastic Industries Ltd), color shade nets of three different colors, namely blue, red and black, with 30\% shading capacity and the control treatment, without the use of a net.

For planting, sacks, denominated slabs measuring 1.50 $\mathrm{m}$ long and $0.35 \mathrm{~m}$ wide, filled with $25 \mathrm{~kg}$ of milled pine bark-based substrate. After filling, they were placed on aluminum benches, with three slabs in parallel disposition for treatment. A drip irrigation system was used was by means of 15 drippers per slab, with daily irrigations until the substrate was saturated. The plastic was perforated with the purpose of avoiding the substrate becoming drenched and affecting the health of the roots. Afterwards, orifices were made for the drippers, and then larger holes for the seedlings, using the staking screen with 10 by 10 centimeters spacing. With the substrate previously wet, the seedlings were planted in the afternoon period. In this experiment, 20 lisianthus seedlings per slab were transplanted, with three repetitions, therefore being 60 plants per treatment and a total of 240 plants. Fertilization by ferti-irrigation began seventeen days after planting, and after this period, was applied weekly until the formation of buds, when it was programmed fortnightly, as recommended by the Fazenda Bom Jardim garden, producer of lisianthus. The agronomic characteristics were evaluated with regard to height of the plants, measured from the base up to the apical meristem in the vegetative stage $(\mathrm{cm})$ at the time intervals of $15,38,59$, 82 and 105 days after transplantation (DAT), period that marked the beginning of harvesting, and the length of the largest pair of leaves (distance from the tip of one leaf up to the tip of the leaf in the opposite direction, in $\mathrm{cm}$ ) in the same vegetative period. The onset of flowering, stem thickness (with the use of a pachymeter right after the sixth node of each plant, during harvesting, in $\mathrm{cm}$ ), weight of stems collected $(\mathrm{g})$ and distance between nodes (as from the fifth node in $\mathrm{cm}$ ), were obtained in the harvesting stage. The point of harvesting during the trial occurred at the time when the stems presented a minimum of three open buds. The experimental design was entirely casualized; data obtained were submitted to the analysis of variance and the mean values of treatments were compared by the Tukey Test at $5 \%$ of probability (SISVAR).

\section{RESULTS AND DISCUSSION}

Statistical analysis demonstrated significant effects of the nets on the variable height of plants throughout the cycle. The plants that developed under the red net presented greater height, as well as more accelerated growth when compared with the other nets, with significant difference between the blue net and control throughout the cycle, and in comparison with the black shade net, the difference was significant up to 59 DAT (Table 1). At 82 DAT up to 105 DAT (beginning of harvesting), the plants developed under the red net continued to present greater development in height with a difference of $10.5 \mathrm{~cm}$ when compared with the control treatment, and $9.8 \mathrm{~cm}$ in comparison with the black shade net (Table 1).

Table 1. Height of plants $(\mathrm{cm})$ and length of pair of leaves $(\mathrm{cm})$ in different periods vegetation in growing lisianthus until $106^{\circ}$ days after transplanting (DAT) in different light transmission nets, blue, red and black, with the control treatment without a color nets.

\begin{tabular}{|c|c|c|c|c|c|}
\hline Height & 15 DAT & 38 DAT & 59 DAT & 82 DAT & 106 DAT \\
\hline Blue & $0.47 \mathrm{~b}$ & $4.03 \mathrm{~b}$ & $9.93 \mathrm{~b}$ & $24.80 \mathrm{~b}$ & $54.08 \mathrm{~b}$ \\
\hline Black & $0.43 \mathrm{bc}$ & $3.94 \mathrm{~b}$ & $10.88 \mathrm{~b}$ & $30.16 \mathrm{ab}$ & $56.81 \mathrm{ab}$ \\
\hline Control & $0.34 \mathrm{c}$ & $2.49 \mathrm{c}$ & $7.27 \mathrm{c}$ & $24.65 \mathrm{~b}$ & $55.46 \mathrm{~b}$ \\
\hline Red & $0.58 \mathrm{a}$ & $6.06 \mathrm{a}$ & $15.13 \mathrm{a}$ & $36.73 \mathrm{a}$ & $66.64 \mathrm{a}$ \\
\hline VC $(\%)$ & 7.5 & 9.14 & 7.04 & 8.93 & 6.31 \\
\hline & & Pair of leaves & & $14.02 \mathrm{a}$ \\
\hline Blue & $3.07 \mathrm{bc}$ & $6.46 \mathrm{~b}$ & $8.57 \mathrm{~b}$ & $12.43 \mathrm{a}$ & $16.02 \mathrm{a}$ \\
\hline Black & $3.34 \mathrm{ab}$ & $8.16 \mathrm{a}$ & $10.94 \mathrm{ab}$ & $15.16 \mathrm{a}$ & $17.04 \mathrm{a}$ \\
\hline Rentrol & $2.91 \mathrm{c}$ & $6.59 \mathrm{~b}$ & $9.47 \mathrm{ab}$ & $15.45 \mathrm{a}$ & $16.30 \mathrm{a}$ \\
\hline
\end{tabular}

Treatments followed by different letters are different at the Tukey $5 \%$ level.

$*$ Difference from $5 \%$ probability $(\underline{p}<0.05)$ 
In accordance with the IBRAFLOR standards for cut flower classification for Lisianthus (IBRAFLOR, 2016), the red net produced flowers classified as long (between 60 and $70 \mathrm{~cm}$ ), while the other treatment produced flowers classified as medium (between 50 and $60 \mathrm{~cm}$ ). This differentiated classification between the treatments presents a remuneration specifically for long and medium stems, with values of $\mathrm{R} \$ 15.00$ and $\mathrm{R} \$ 10.00$ respectively. The same did not occur for the cultivation of Anthurium; Nomura et al. (2009), evaluated nets with $70 \%$ shading in the colors black, red, blue and heat reflector for the cultivar "Apalai". In this trial, the authors found more expressive results in the treatment for the black shade net on the characteristics of the floral height and stem, length and width of the sheath, providing better growing conditions for the cultivar studied. Up to the 59 DAT, the blue and black nets presented significant difference when compared with the control, in the requisite stem height, however, after this date, there was no longer any significant difference among these three treatments, demonstrating that there was interaction between the net and plant in the beginning of the cycle.

Oren-Shamir et al. (2001), in his study, pointed out that when using the photoselective nets, we cause different changes in the wavelength of radiation within the protected environment, particularly with regard to the close red/far red $(\mathrm{R} / \mathrm{FR})$ ratio. Thus, when observing the transmittance of the red photoselective net, it is verified that in addition to transmitting the red band as expected, it presents lower transmittance in the close red (R) and greater transmittance in the far red (FR). Therefore, the red photoselective net generally promotes elongation between the nodes and stem length. Whereas, the blue net in turn, presents the same levels of transmittance in the close and far red, which generally results in the response of dwarfism by the plant.

With regard to size of the largest pair of leaves of the plant (Table 1), up to the 38 DAT the authors found that the red and black nets did not differ significantly, however, they differed with regard to the other treatments. Therefore, these two treatments showed an initial accelerated growth, in comparison with the treatments evaluated. At the 59 DAT, the blue net was the only one that differed from the others, however, being shown as that with the shortest lengths of the pair of leaves. After this date, the authors detected no significant difference between the treatments.

According to Rajapakse and Shahak (2007), the effects of photoselective nets were firstly studied in ornamental plants, and in various experiments, the results were that the red and yellow photoselective nets stimulated the rate of vegetative growth and vigor, while the blue nets caused dwarfism in Pittosporum variegatum (Japaneses Pittosporum) and Philodendron monstera (Adam's Rib).

The precocious development in the treatment with the red net was observed with anticipated removal of the stems in nine days, when compared with the other treatments (Table 2). The later harvest occurred under the treatment with the blue net, starting 15 days afterwards. The precocious development of production may be related to the responses of the phytochrome to increase in the incidence of far red in the plants, which stimulated elongation of the stem, vigor and most probably, flowering.

Table 2. Harvest start dates in days after transplanting (DAT) of lisianthus stems with a minimum of three open buttons in different light transmission nets, blue, red and black, with the control treatment without a color nets.

\begin{tabular}{|c|c|c|}
\hline Treatments & Initial Harvest & DAT \\
\hline Blue & $21 / 10 / 2014$ & 121 \\
\hline Black & $15 / 10 / 2014$ & 115 \\
\hline Control & $16 / 10 / 2014$ & 116 \\
\hline Red & $06 / 10 / 2014$ & 106 \\
\hline
\end{tabular}

Acceleration in development may be related to the higher level of energy available for photosynthetic activity, in the microenvironment created under the red net, causing positive changes in the vegetative development of the cultivar studied Rajapakse and Shahak (2007). The precocious development demonstrated under the red net represents a gain in productivity to the producer, which must be considered a significant benefit when investing in this technology.
Among the characteristics evaluated in the harvesting stage (Table 3), the distance between nodes, evaluated at 106 DAT, presented significant difference, so that the greatest distance was obtained in the treatment under the red net, as has been described by Oren-Shamir et al. (2001) and Rajapakse and Shahak (2007). 
Table 3. Evaluations conducted under lisianthus crop in different treatments nets on the distance between node (cm), thick stem $(\mathrm{cm})$ and weight stem $(\mathrm{g})$.

\begin{tabular}{|c|c|c|c|}
\hline Treatments & Distance between node $(\mathbf{c m})$ & Thick stem $(\mathbf{c m})$ & Weight stem (g) \\
\hline Blue & $3.95 \mathrm{~b}$ & $0.42 \mathrm{a}$ & $41.30 \mathrm{a}$ \\
\hline Black & $4.29 \mathrm{~b}$ & $0.53 \mathrm{a}$ & $60.62 \mathrm{a}$ \\
\hline Control & $4.38 \mathrm{~b}$ & $0.55 \mathrm{a}$ & $55.27 \mathrm{a}$ \\
\hline Red & $5.15 \mathrm{a}$ & $0.51 \mathrm{a}$ & $57.58 \mathrm{a}$ \\
\hline VC $(\%)$ & 3.46 & 9.42 & 24.12 \\
\hline
\end{tabular}

Treatments followed by different letters are different at the Tukey $5 \%$ level.

*Difference from $5 \%$ probability $(p<0.05)$

The other characteristics evaluated did not result in statistically significant differences, however they presented important differences for the producer (Table 3 ); the thickness of stems showed greater difference when the control treatment was compared with the blue net treatment, the latter treatment was that showing the smallest stem thickness. This characteristic is important, because it is related to the physical resistance to falling down, torsion and breakage of the stem. As regards the weight of the stem harvested, the greatest difference in data obtained was between the treatment with the black net and that of treatment with the blue net, and once again, the blue net obtained the lowest results, characterizing a thin, light stem. Among the other treatments, there was little and no significant difference. According to the IBRAFLOR standards for the classification of cut flowers for lisianthus (IBRAFLOR, 2016) a saleable bunch must contain 500 grams; therefore, the producer would place a larger number of flower stems coming from the blue net into this bunch, than if the flowers came from the other treatments. When using a lower number of flower stems per bunch, producers increase the yield of their production.

\section{CONCLUSIONS}

The use of light transmitting nets red color is recommended for growing lisianthus. The agronomic characteristics evaluated, such as stem height, and precocious harvesting were superior to those of the other treatments evaluated.

\section{REFERENCES}

BACKES, F.A.A. L.; BARBOSA, J.G.; BACKES, R.L.; RIBEIRO, J.M.O.; MORITA, R.M. Produção de Lisianthus (Eustoma grandiflorum Shinn.) em vaso sob diferentes densidades de plantas. Acta Scientiarum Agronomy, v.27, p.237-241, 2005.

CORR, B.; KATZ, P.A grower's guide to lisianthus production. Floraculture International, v.7, p.16-20, 1997.
HARBAUGH, B.K. Lisianthus. In: Anderson, N.O. (ed.). Issues, Challenges and Opportunities for the 21st Century. Netherlands: Springer, 2006. p.644-663.

INSTITUTO BRASILEIRO DE FLORICULTURA IBRAFLOR, 2016. Critério de classificação Lisianthus corte. Disponível em: www.ibraflor.com/publicacoes/ vw.php?cod=163. Acesso em: abril de 2016.

LEITE, C.A.; ITO, R.M.; LEE, G.T.S.; GANELEVIN, R.; FAGNANI, M.A. Light spectrum management using colored nets to control the growth and blooming of phalaenopsis. Acta Horticulturae, v.770, p.177-184, 2008. DOI: http://dx.doi.org/10.17660/ActaHortic.2008.770.20

NOMURA, E.S.; LIMA, J.D.; FUZITANI, E.J.; SILVA, S.H.; GARCIA, V.A.; TOMBOLATO, A.C. Crescimento e produção de antúrio submetido a diferentes intensidades de desfolha. Ciência Rural, v.41, p.602-607, 2011.

OREN-SHAMIR, M.; GUSSAKOVSKY, E.E.; SHPIEGEL, E.; NISSIM-LEVI, A.; RATNER, K.; OVADIA, R., GILLER, Y.; SHAHAK, Y. Colored shade nets can improve the yield and quality of green decorative branches of Pittosphorum variegatum. Journal Horticulture Science Biotechnology, v.76, n.3, p.353361, 2001.

RAJAPAKSE, N.C.; SHAHAK, Y. Light quality manipulation by horticulture industry. In: WHITELAM, G.; HALLIDAY, K. (Ed.). Light and Plant Development. UK: Blackwell Publishing, 2007. p.290-312.

STAMPS, R.H.; CHANDLER, A.L. Differential effects of colored shade nets on three cut foliage crops. Acta Horticulturae, v.770, p.169-176, 2008. DOI: http://dx.doi. org/10.17660/ActaHortic.2008.770.19

STRUWE, L.; ALBERT, V.A. Gentianaceae - Systematics and natural history. Cambrige: University Press, 2002. $625 \mathrm{p}$. 